\title{
HLA-C*0802 Positive Cells Present
}

National Cancer Institute

\section{Source}

National Cancer Institute. HLA-C*0802 Positive Cells Present. NCI Thesaurus. Code

C163011.

An indication that cells expressing HLA-C*0802 have been detected in a sample. 